\title{
EFFECT OF LIMING ON THE MOBILIZATION OF SOIL PHOSPHORUS
}

\author{
Armi KaILA \\ University of Helsinki, Department of Agricultural Chemistry
}

Received March 3, 1965

Results of numerous field and pot experiments indicate that judicious liming of acid soils usually improves the uptake of phosphorus by plants. There is, however, no universal agreement among the investigators about the factors involved. The traditional explanations that liming makes soil phosphorus more available either by intensifying the mineralization of organic phosphorus or by rendering difficultly soluble inorganic forms more easily soluble have not yet been proved by experimental evidence under the field conditions.

GERICKE (9) claims that the influence of liming on the mobilization of soil phosphorus is of minor importance, and that the improvement of the general growing conditions, particularly the decrease in acidity, will be the decisive factor. In this connection attention is also due to the hypothesis presented by RUSSEL (19) that the iron and aluminium ions present in the acid soils reduce the ability of the plant roots to translocate phosphorus from the soil to the tops, probably, because part of the phosphate is restrained in roots (8). BoHne (3) supposes that the favourable effect of liming on the root growth of plants accounts for the higher uptake of phosphorus. Aslander (24) attributes the better utilization of soil phosphorus primarily to the promotion of humus decomposition by liming which increases the nitrate production from soil organic nitrogen and the formation of certain humus fractions which are likely to increase the solubility of soil phosphorus.

On the other hand, it is obvious that application of lime to an acid soil may disturb the dynamic equilibrium between the forms of soil phosphorus. This has been demostrated by chemical analyses of samples from field experiments and under laboratory conditions. Parker and Tidmore (18) showed that the phosphorus concentration in the soil solution and water extracts was higher in the plots treated with lime than in the corresponding untreated ones. The solubility of phosphorus in acid extractants, e.g acetic acid, acid lactate, and diluted mineral acids, is usually increased by liming $(1,10,12,15,20)$, although this does not seem to be always the case $(2,5)$. Chang and Jackson (5) found that application of lime has little 
effect on the relative abundance of the phosphorus bound by aluminium, iron, or calcium in a podzolic silt loam soil, but in an other silt loam soil the lack of crop response to added phosphate was explained, at least partly, on the basis of the release of phosphorus by decrease of aluminium and iron activity through liming. When strongly acidic highly weathered soils underwent an increase in $\mathrm{pH}$ by $\mathrm{CaCO}_{3}$ addition, a slow back-transformation to calcium-bound phosphate occurred but considerable aluminium-bound and iron-bound phosphate persisted (13). HEINEMANN (12) could not detect significant differences in the distribution of soil phosphorus between the limed and unlimed plots in three field experiments on sand and loam soils.

Although the favourable effect of liming on the phosphorus availability in acid soils is often to a large extent attributed to the mineralization of organic phosphorus $(7,20,21,23$ etc.) the evidence is usually inadequate. Damsganad-Sørensen (6) found that in old field experiments heavy liming had decreased the amount of phosphorus in organic form, and the writer's results (14) indicate that in field experiments on a couple of fen peat soils the organic phosphorus content tended to be lower in the limed plots than in the unlimed ones. In other experiments studied this was not the case, probably partly because the higher yields of the limed plots take up more phosphorus but also leave in the soil more organic matter than the lower yields of the unlimed plots. In the field experiments studied by DORPHPetersen (7), an apparently significant decrease in the organic phosphorus content is detectable in one of the soils, but he supposes that the acceleration of the rate of the mineralization of organic phosphorus may be a contributory cause of the increased uptake of phosphorus due to liming, even when the chemical soil analyses are not capable of proving it, owing to the large variability of soil, the sampling errors, and the relatively low accuracy of the methods.

Also in incubation experiments under the laboratory conditions, the inaccuracy of the determination of soil organic phosphorus hampers the demonstration of the changes in this fraction, since differences in the organic P less than about $20 \mathrm{ppm}$ are seldom significant (16). The decline in the organic phosphorus content due to liming, often does not exceed this limit. Recently HaLstead et al. (11) reported that in their laboratory experiment, liming resulted in an average decrease of 8 ppm or 3.6 per cent of the total content of organic phosphorus in acid surface soils incubated for 9 months. The writer (14) incubated various kinds of acid soil samples for 6 months at room temperature, and found that the organic phosphorus content of the samples incubated with 2 per cent $\mathrm{CaCO}_{3}$ was from 0 to $50 \mathrm{ppm}$ or from 0 to 3.5 per cent lower than that in the corresponding soils incubated without lime. Only in an acid muddy clay soil the decline due to liming was as high as $100 \mathrm{ppm}$ or 12 per cent of the organic phosphorus content in the unlimed sample.

In a previous paper (15) results were reported on the effect of liming on the phosphorus fractions of a loam soil and a silt soil during incubation for 7 months. An addition of 1 per cent $\mathrm{CaCO}_{3}$ did not increase the mineralization of organic phosphorus. Its effect was detectable in the distribution of inorganic phosphorus, as a decrease in the alkali-soluble fraction and an increase in the $\mathrm{NH}_{4} \mathrm{Cl}$-soluble form and in the acid-soluble or $\mathrm{NH}_{4} \mathrm{~F}$-soluble fractions. These soils were not particularly acid, 
and since it is likely that the effect of lime would be more pronounced on more acid samples, the studies were continued on a larger material containing also this kind of soils. The main purpose of the present work is to find out whether the possible mobilization of soil organic phosphorus by liming is mainly due to the mineralization of organic phosphorus, or to the changes in the fractions of the inorganic forms.

\section{Material and methods}

The material of the present study consists of 22 samples from the surface layer of cropped soils and of 7 samples from the surface layer of virgin lands. In addition, 5 samples from the depths of 30 to $40 \mathrm{~cm}$ or 40 to $60 \mathrm{~cm}$ were included. The samples are listed in Table 1.

Table 1. Soil samples

\begin{tabular}{|c|c|c|c|c|c|c|c|c|}
\hline \multirow{2}{*}{\multicolumn{2}{|c|}{ Sample }} & \multirow{2}{*}{$\mathrm{pH}$} & \multirow{2}{*}{$\underset{\%}{\text { Org. C }}$} & \multirow{2}{*}{$\begin{array}{l}\text { Org. P } \\
\text { ppm }\end{array}$} & \multicolumn{4}{|c|}{ Inorg. P ppm extracted by } \\
\hline & & & & & $\mathrm{NH}_{4} \mathrm{Cl}$ & $\mathrm{NH}_{4} \mathrm{~F}$ & $\mathrm{NaOH}$ & $\mathrm{H}_{2} \mathrm{SO}_{4}$ \\
\hline \multicolumn{9}{|c|}{ Cultivated soils } \\
\hline C $5 \mathrm{~S}$ & Sand & 5.1 & 6.9 & 560 & 1 & 69 & 78 & 46 \\
\hline C 1 & Finesand & 5.1 & 1.9 & 230 & 1 & 39 & 69 & 252 \\
\hline C 2 & $\rightarrow$ & 5.3 & 2.9 & 260 & 1 & 36 & 11 & 33 \\
\hline Mi $2 \mathrm{a}$ & $\rightarrow$ & 5.4 & 3.5 & 180 & 2 & 184 & 150 & 99 \\
\hline Mi $4 \mathrm{a}$ & $\rightarrow-$ & 5.6 & 5.6 & 280 & 1 & 139 & 114 & 170 \\
\hline $\mathrm{Vi} 4 \mathrm{a} I$ & Loam & 4.3 & 5.0 & 370 & 2 & 94 & 144 & 194 \\
\hline Ha 13 & $\rightarrow$ & 4.7 & 4.0 & 370 & 5 & 78 & 113 & 156 \\
\hline L 11 & $\rightarrow$ & 4.9 & 3.8 & 440 & 2 & 101 & 183 & 139 \\
\hline C 3 & Silt & 4.5 & 4.2 & 360 & 3 & 107 & 207 & 231 \\
\hline Ra 1 & $\rightarrow$ & 5.3 & 6.4 & 660 & 5 & 295 & 320 & 225 \\
\hline Ra 3 & $\rightarrow$ & 5.3 & 2.5 & 310 & 1 & 32 & 161 & 258 \\
\hline VN & Clay loam & 4.5 & 5.8 & 570 & 2 & 90 & 506 & 183 \\
\hline VN 2 & $\rightarrow-$ & 5.1 & 4.6 & 470 & 2 & 154 & 476 & 204 \\
\hline $\mathrm{Vi} 11 \mathrm{~s}$ & Sandy clay & 4.8 & 3.6 & 220 & 1 & 83 & 226 & 278 \\
\hline C 7 & $\rightarrow-$ & 6.0 & 3.6 & 320 & 4 & 63 & 192 & 444 \\
\hline Vi las & Silty clay & 3.5 & 2.9 & 170 & 1 & 23 & 342 & 195 \\
\hline Ha 32 & $\rightarrow$ & 4.8 & 5.5 & 370 & 1 & 43 & 328 & 107 \\
\hline C 6 & $\rightarrow-$ & 5.0 & 4.6 & 410 & 1 & 87 & 251 & 112 \\
\hline O $2 a$ & $\rightarrow-$ & 5.1 & 6.5 & 540 & 1 & 135 & 279 & 206 \\
\hline PN 11 & Heavy clay & 4.9 & 5.6 & 740 & 1 & 96 & 159 & 56 \\
\hline LN 1 & $\rightarrow-$ & 5.1 & 2.6 & 390 & 1 & 25 & 125 & 72 \\
\hline Кö & $\rightarrow$ & 5.5 & 2.6 & 360 & 2 & 47 & 242 & 403 \\
\hline \multicolumn{9}{|c|}{ Virgin soils } \\
\hline C $4 \quad 5$ & Sand & 4.4 & 6.3 & 280 & 2 & 29 & 38 & 25 \\
\hline Mi la 1 & Finesand & 4.3 & 5.5 & 210 & 7 & 29 & 55 & 22 \\
\hline Mi $3 a$ & $\rightarrow-$ & 4.0 & 5.1 & 280 & 4 & 35 & 46 & 38 \\
\hline Vi 6 a I & Loam & 4.2 & 2.9 & 230 & 2 & 78 & 413 & 140 \\
\hline Кӧ 1 & $\rightarrow-$ & 4.5 & 5.2 & 500 & 2 & 32 & 124 & 277 \\
\hline $\operatorname{Ra} 5$ & Silt & 4.5 & 3.8 & 280 & 2 & 16 & 96 & 284 \\
\hline LL 9 s & Silty clay & 4.9 & 6.5 & 580 & 2 & 18 & 47 & 38 \\
\hline \multicolumn{9}{|c|}{ Subsoil samples } \\
\hline $\mathrm{Vi} \mathrm{4c}$ & Clay loam & 4.0 & 0.4 & 30 & 0 & 15 & 259 & 197 \\
\hline $\mathrm{Vi} 6 \mathrm{c}$ & $\rightarrow-$ & 4.1 & 2.0 & 200 & 1 & 23 & 140 & 274 \\
\hline Vi lc & Silty clay & 3.3 & 2.2 & 160 & 1 & 12 & 340 & 173 \\
\hline Kö 7 & $\rightarrow$ & 5.9 & 2.0 & 250 & 1 & 16 & 168 & 392 \\
\hline Vi 12 & $\rightarrow$ & 4.2 & 0.6 & 50 & 1 & 23 & 140 & 274 \\
\hline
\end{tabular}


The soil $\mathrm{pH}$ was determined in a $1: 2.5$ suspension of soil to solution in 0.01 $\mathrm{M} \mathrm{CaCl}_{2}$. The organic carbon was estimated by a modified procedure of Walkley.

The organic phosphorus represents the average of the values obtained by the writer's acid-alkali extraction and ignition methods (16). The fractions of inorganic

Table 2. Increase or decrease in soil $\mathrm{P}$ fractions due to incubation (a) or to incubation and liming (b).

\begin{tabular}{|c|c|c|c|c|c|c|c|c|c|}
\hline & & & \multirow{2}{*}{$\mathrm{pH}$} & \multicolumn{4}{|c|}{ Inorg. $\mathrm{P}$ ppm extracted by } & \multirow{2}{*}{$\begin{array}{c}\text { Total } \\
\text { inorg. P } \\
\text { extracted }\end{array}$} & \multirow{2}{*}{$\begin{array}{l}\text { Org. P } \\
\text { ppm }\end{array}$} \\
\hline & & & & $\mathrm{NH}_{4} \mathrm{Cl}$ & $\mathrm{NH}_{4} \mathrm{~F}$ & $\mathrm{NaOH}$ & $\mathrm{H}_{2} \mathrm{SO}_{4}$ & & \\
\hline \multicolumn{10}{|c|}{ Cultivated soils } \\
\hline \multirow[t]{2}{*}{ C } & 5 & a & 4.6 & 0 & $15 * * *$ & 14 & 0 & 29 & -9 \\
\hline & & $\mathrm{b}$ & 6.7 & 0 & $16^{* * *}$ & 6 & 6 & 28 & -12 \\
\hline \multirow[t]{2}{*}{ C } & 1 & $\mathrm{a}$ & 4.7 & 0 & $6^{*}$ & 1 & 1 & 8 & -19 \\
\hline & & $\mathrm{b}$ & 7.2 & 1 & $13^{* * *}$ & $-13^{* * *}$ & $13^{* *}$ & $14^{* *}$ & $-21^{*}$ \\
\hline \multirow[t]{2}{*}{$\mathrm{C}$} & 2 & $\mathrm{a}$ & 4.9 & 0 & $6^{*}$ & 1 & 0 & $7 *$ & -7 \\
\hline & & $\mathrm{b}$ & 7.0 & 1 & $8^{*}$ & -1 & 0 & $8^{*}$ & -18 \\
\hline \multirow[t]{2}{*}{ Mi } & $2 \mathrm{a}$ & $\mathrm{a}$ & 5.0 & $-1^{*}$ & 2 & 0 & -8 & -7 & -10 \\
\hline & & b & 7.1 & 0 & 13 & -11 & $30 * *$ & $32^{*}$ & -16 \\
\hline \multirow[t]{2}{*}{ Mi } & $4 \mathrm{a}$ & $\mathrm{a}$ & 5.3 & 0 & 4 & -3 & 0 & 1 & $-23^{*}$ \\
\hline & & $\mathrm{b}$ & 7.1 & 1 & 8 & $-16^{*}$ & $36^{*}$ & 29 & $-28^{*}$ \\
\hline \multirow[t]{2}{*}{$\mathrm{Ha}$} & 13 & $\mathrm{a}$ & 4.5 & $-3^{* * *}$ & 6 & $8^{* *}$ & -2 & 9 & -12 \\
\hline & & b & 6.2 & $-3^{* * *}$ & $12^{* *}$ & -1 & 0 & 8 & -12 \\
\hline \multirow[t]{2}{*}{ L } & 11 & $\mathrm{a}$ & 4.3 & 0 & $15^{* * * *}$ & 4 & 0 & 19 & -18 \\
\hline & & $\mathrm{b}$ & 6.8 & 0 & $26^{* * *}$ & -10 & $16^{*}$ & $32 *$ & $-20^{*}$ \\
\hline \multirow[t]{2}{*}{$\mathrm{C}$} & 3 & $\mathrm{a}$ & 4.1 & 0 & $8^{* *}$ & 2 & -2 & 8 & -5 \\
\hline & & $\mathrm{b}$ & 6.7 & 1 & $25^{* * *}$ & $-17 * * *$ & $15^{* *}$ & $24^{* * *}$ & $-27^{* *}$ \\
\hline \multirow[t]{2}{*}{ Ra } & 1 & $\mathrm{a}$ & 4.8 & 0 & $16^{*}$ & 14 & 5 & $35^{* *}$ & $-26^{*}$ \\
\hline & & b & 6.8 & $6^{* * *}$ & $33^{* * *}$ & -15 & $31^{* * *}$ & $55^{* * *}$ & $-30^{* *}$ \\
\hline \multirow[t]{2}{*}{$\mathrm{Ra}$} & 3 & a & 4.7 & 0 & $11^{* * *}$ & $27 * * *$ & 2 & $40 * * *$ & $-28^{*}$ \\
\hline & & b & 7.0 & $1^{*}$ & $19^{* * *}$ & -2 & $14^{* * *}$ & $32^{* * *}$ & $-27^{*}$ \\
\hline \multirow[t]{2}{*}{ VN } & 1 & $\mathrm{a}$ & 4.1 & -1 & 3 & 0 & -20 & -18 & 3 \\
\hline & & b & 6.0 & 0 & $22^{* * *}$ & -11 & 1 & 12 & -10 \\
\hline \multirow[t]{2}{*}{$\mathrm{VN}$} & 2 & $\mathrm{a}$ & 4.6 & 0 & 3 & $31^{*}$ & -12 & 22 & -20 \\
\hline & & b & 6.6 & $2^{*}$ & $31^{* * *}$ & -18 & $21^{*}$ & $36^{*}$ & -11 \\
\hline \multirow[t]{2}{*}{ Vi } & 11 & $\mathrm{a}$ & 4.5 & 0 & 1 & 14 & 1 & 16 & -9 \\
\hline & & $\mathrm{b}$ & 7.0 & 1 & $20 * * *$ & $-14^{*}$ & $23^{*}$ & $30^{*}$ & -14 \\
\hline \multirow[t]{2}{*}{ C } & 7 & $\mathrm{a}$ & 5.5 & 0 & $11^{*}$ & $15^{* *}$ & -1 & 25 & -13 \\
\hline & & $\mathrm{b}$ & 7.1 & $4^{* * *}$ & $19^{* *}$ & $-24 * * *$ & $31^{* *}$ & $30^{*}$ & $-24^{*}$ \\
\hline \multirow[t]{2}{*}{$\mathrm{Ha}$} & 32 & $\mathrm{a}$ & 4.3 & 0 & 3 & 9 & 7 & 19 & -7 \\
\hline & & b & 6.4 & 1 & $20 * * *$ & -23 & $25^{* * *}$ & $23^{*}$ & -18 \\
\hline \multirow[t]{2}{*}{$\mathrm{C}$} & 6 & $\mathrm{a}$ & 4.6 & 0 & 2 & 3 & -3 & 2 & -11 \\
\hline & & $\mathrm{v}$ & 6.8 & 0 & $24 * * *$ & $-30^{* *}$ & $27 * *$ & 21 & $-34^{* *}$ \\
\hline \multirow[t]{2}{*}{$\mathrm{O}$} & $2 \mathrm{a}$ & $\mathrm{a}$ & 4.5 & 1 & 6 & 12 & -3 & 16 & $-36^{* *}$ \\
\hline & & b & 6.6 & $2^{* *}$ & $30^{* * *}$ & $-17^{*}$ & $20 * *$ & $35^{*}$ & $-39^{* *}$ \\
\hline \multirow[t]{2}{*}{ PN } & 1 & $\mathrm{a}$ & 4.5 & 0 & 1 & 1 & 4 & 6 & -2 \\
\hline & & $\mathrm{b}$ & 6.4 & 0 & 6 & $-16^{* * *}$ & 8 & -2 & 6 \\
\hline $\mathrm{LN}$ & 1 & a & 4.8 & 0 & -1 & $19^{*}$ & 3 & $21^{*}$ & $-27^{*}$ \\
\hline & & b & 7.0 & 1 & 6 & -1 & 11 & $17 *$ & $-31^{* *}$ \\
\hline Kö & 3 & $\mathrm{a}$ & 4.8 & 0 & 2 & 4 & -7 & -1 & -3 \\
\hline & & b & 7.2 & $4^{* * *}$ & $26^{* * *}$ & $-33^{* * *}$ & 16 & 13 & -16 \\
\hline
\end{tabular}




\begin{tabular}{|c|c|c|c|c|c|c|}
\hline \multirow{2}{*}{$\mathrm{pH}$} & \multicolumn{4}{|c|}{ Inorg. $\mathrm{P}$ ppm extracted by } & \multirow{2}{*}{$\begin{array}{c}\text { Total } \\
\text { inorg. P } \\
\text { extracted }\end{array}$} & \multirow{2}{*}{$\begin{array}{c}\text { Org. P } \\
\text { ppm }\end{array}$} \\
\hline & $\mathrm{NH}_{4} \mathrm{Cl}$ & $\mathrm{NH}_{4} \mathrm{~F}$ & $\mathrm{NaOH}$ & $\mathrm{H}_{2} \mathrm{SO}_{4}$ & & \\
\hline
\end{tabular}

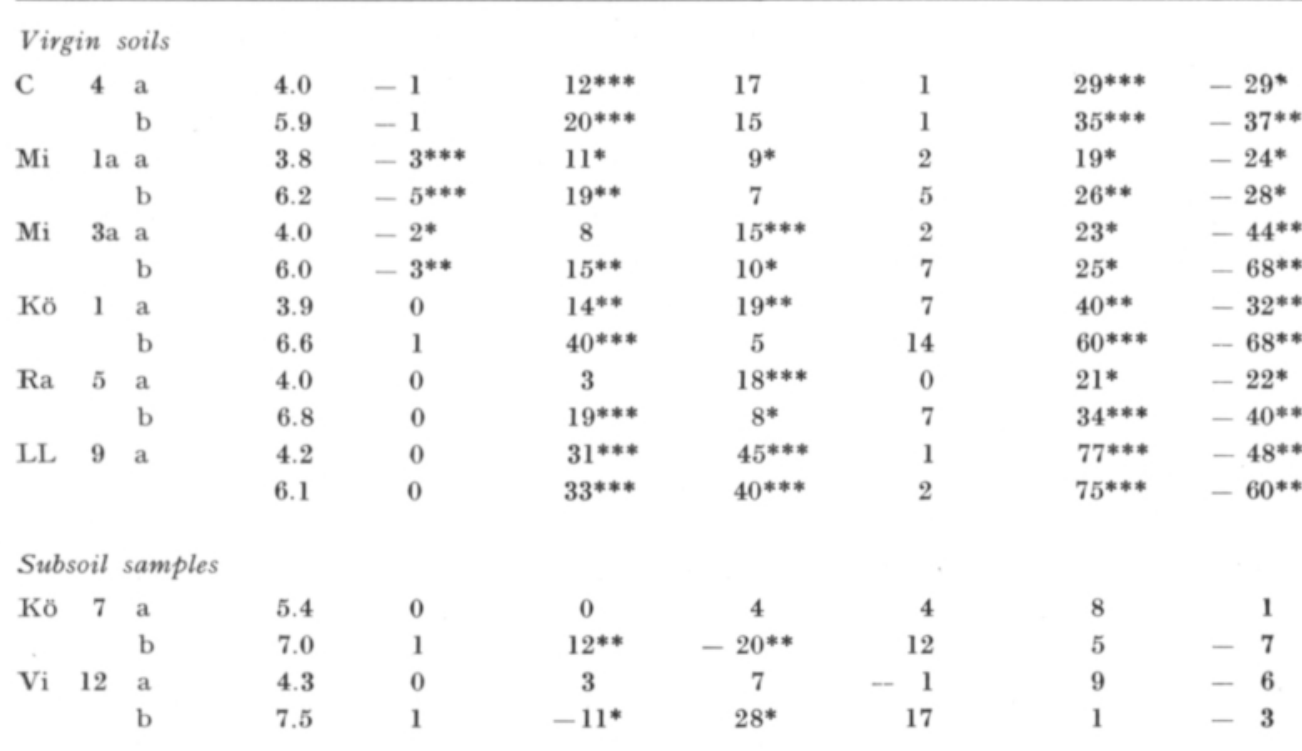

phosphorus were determined by the method of CHANG and JACKson (4) using a slightly alkaline $\mathrm{NH}_{4} \mathrm{~F}$-solution.

Two incubation experiments were carried out. In the first one $100 \mathrm{~g}$ of airdry and ground soil was weighed into a glass jar, moistened with distilled water to the field capacity, and incubated at about $20^{\circ} \mathrm{C}$ for 6 months. Before the moistening, $1 \mathrm{~g}$ of $\mathrm{CaCO}_{3}$ was added to a second set of samples and thoroughly mixed. At the end of the incubation period the samples were air-dried and ground. The second incubation experiment was performed in a similar way, only lime was applied at the rates of $0,5,10$, or $20 \mathrm{~g}$ per kilogram of soil.

\section{Results}

The results of the first incubation experiment are recorded in Table 2 as the differences in the phosphorus content of the various fractions between the samples incubated with or without lime and the original samples. The $\mathrm{pH}$-values were determined at the end of the incubation period, and they show in most of the samples the typical increase in the acidity due to the incubation without an application of lime and on the other hand, they prove that the application of 1 per cent $\mathrm{CaCO}_{3}$ has kept most samples almost neutral even at the end of the incubation period. pH-values determined after three weeks' incubation were in the unlimed samples usually somewhat higher than those measured at the end of the six months' period, but no significant difference exists between the respective $\mathrm{pH}$-values of the limed samples.

The changes brought about by incubation or by incubation and liming in the small amount of easily soluble inorganic phosphorus in these samples are in most 
cases insignificant, and it is of interest to note that even in the limed samples a decrease in this fraction may be found.

In most soils $\mathrm{NH}_{4} \mathrm{~F}$-soluble phosphorus has accumulated, particularly in the limed samples. The alkali-soluble fraction, on the other hand, is often increased in the unlimed samples, but decreased in several of the limed samples. In the virgin soils, this fraction has grown also in the limed samples although less than in the unlimed ones, probably, since in these samples the $\mathrm{pH}$-values are relatively low.

Incubation without lime has not caused any significant changes in the acidsoluble phosphorus. When the difference in the acid-soluble fraction is significant between the samples incubated with lime and the original samples, it is always positive. This is the case in almost one half of the samples. It appears that the final $\mathrm{pH}$-value measured in $0.01 \mathrm{M} \mathrm{CaCl}_{2}$ is at least 6.4 in these samples. On the other hand, there are samples the $\mathrm{pH}$ of which has been kept higher than 7 without any detectable increase in the acid-soluble phosphorus.

The last column contains the differences in the organic phosphorus content of the incubated and original samples. In almost all soils a decrease in this fraction is found, but owing to the inaccuracy of the methods this decrease is significant only in less than one half of the cases. Particularly in the virgin soils the decrease in the organic phosphorus is marked: without liming the incubation has decreased it 24 to $48 \mathrm{ppm}$ or, on the average, about 11 per cent, and the incubation with lime has caused a decrease of 28 to $68 \mathrm{ppm}$, corresponding averagely to 15 per cent of the organic phosphorus in the original sample. In the samples from the plough layer, the effect has been markedly lower: 23 to $36 \mathrm{ppm}$ or about 7 per cent in the unlimed samples, and 20 to $39 \mathrm{ppm}$ corresponding to an average of somewhat more than 7 per cent in the samples incubated with lime.

In samples where the incubation has brought about a decline in the organic phosphorus content, an increase in the total inorganic phosphorus extracted by the fractionation procedure may be usually found, but these changes are not in all cases equal. This is likely to be due more to the inaccuracy of the determinations than to changes in the inorganic phosphorus involving the occluded forms.

On the basis of these results it seems that the presence of lime in the samples incubated has intensified the accumulation of $\mathrm{NH}_{4} \mathrm{~F}$-soluble phosphorus and probably also the mineralization of organic phosphorus. Apparently it has tended to increase the acid-soluble fraction, but prevented any accumulation of alkali-soluble phosphorus. The data reported in Table 3 offer a more detailed view of the effect of liming in this experiment. They represent the differences between the respective phosphorus fractions in the samples incubated with or without lime.

It appears that only in four samples liming has intensified the mineralization of organic phosphorus to such a degree that the difference is statistically significant. These samples were not more acid than the other ones. The decrease in the alkalisoluble fraction is usually quite marked, and the same is true with the increase in the acid-soluble fraction in the samples of the cultivated soils.

To sum up these results the average increases or decreases in the phosphorus fractions in this experiment were calculated and the following data expressed as $\mathrm{P}$ ppm were found: 
Table 3. Increase or decrease in the $\mathrm{P}$ fractions due to liming

\begin{tabular}{|c|c|c|c|c|c|c|c|}
\hline & & \multicolumn{4}{|c|}{ Inorganic $\mathrm{P}$ ppm extracted by } & \multirow{2}{*}{$\begin{array}{l}\text { Total } \\
\text { inorg. } \mathrm{P} \\
\text { ppm }\end{array}$} & \multirow{2}{*}{$\begin{array}{l}\text { Org. F } \\
\text { ppm }\end{array}$} \\
\hline & & $\mathrm{NH}_{4} \mathrm{Cl}$ & $\mathrm{NH}_{4} \mathrm{~F}$ & $\mathrm{NaOH}$ & $\mathrm{H}_{2} \mathrm{SO}_{4}$ & & \\
\hline \multicolumn{8}{|c|}{ Cultivated soils } \\
\hline C & 5 & 0 & 1 & -8 & 6 & -1 & -3 \\
\hline C & 1 & 1 & $7^{*}$ & $-14^{* * *}$ & $12^{* * *}$ & 6 & -2 \\
\hline C & 2 & 1 & 2 & -2 & 0 & 1 & -11 \\
\hline Mi & $2 \mathrm{a}$ & 1 & 11 & -11 & $38^{* * *}$ & $39 * *$ & -6 \\
\hline Mi & 4 a & $1^{*}$ & 4 & $-13^{*}$ & $36^{*}$ & 28 & -5 \\
\hline $\mathrm{Ha}$ & 13 & 0 & 6 & $-9^{* * *}$ & 2 & -1 & 0 \\
\hline $\mathrm{L}$ & 11 & 0 & $11^{* *}$ & -14 & $16^{*}$ & 13 & -2 \\
\hline C & 3 & 1 & $17 * * *$ & $-19^{* * *}$ & $17 * * *$ & $16^{*}$ & $-22^{*}$ \\
\hline $\mathrm{Ra}$ & 1 & $6 * * *$ & $17^{*}$ & $-29^{*}$ & $26^{* * *}$ & 20 & -4 \\
\hline $\mathrm{Ra}$ & 3 & $1^{*}$ & $8^{*}$ & $-29 * * *$ & $12^{* * *}$ & -8 & 1 \\
\hline VN & 1 & 1 & $19 * * *$ & -11 & 21 & $30^{*}$ & -13 \\
\hline VN & 2 & $2^{*}$ & $28^{* * *}$ & $-49^{* *}$ & $33^{* *}$ & 14 & 9 \\
\hline Vi & 11 & 1 & $19 * * *$ & $-28^{* * *}$ & $22^{*}$ & 14 & -5 \\
\hline C & 7 & $4^{* * * *}$ & 8 & $-39^{* * *}$ & $32^{* * *}$ & 5 & -11 \\
\hline $\mathrm{Ha}$ & 32 & 1 & $17 * * *$ & $-32^{*}$ & $18^{* *}$ & 4 & -11 \\
\hline C & 6 & 0 & $22^{* * *}$ & $-33^{* *}$ & $30^{* * *}$ & 19 & $-23^{*}$ \\
\hline $\mathrm{O}$ & $2 \mathrm{a}$ & $1^{*}$ & $24^{* * *}$ & $-29^{* *}$ & $23^{* * *}$ & 19 & -3 \\
\hline PN & 1 & 0 & 5 & $-17^{* * *}$ & 4 & -8 & 8 \\
\hline LN & 1 & 1 & 7 & $-20^{*}$ & 8 & -4 & -4 \\
\hline Kö & 3 & $4^{* * *}$ & $24 * * *$ & $-37 * * *$ & $23^{*}$ & 14 & -13 \\
\hline
\end{tabular}

Virgin soils

$\begin{array}{lllllrrr}\mathrm{C} & 4 & 0 & 8^{* * *} & -2 & 0 & 6 & -8 \\ \mathrm{Mi} & 1 \mathrm{a} & -2^{*} & 8 & -2 & 3 & 7 & -4 \\ \mathrm{Mi} & 3 \mathrm{a} & -1^{*} & 7 & -5 & 5 & 2 & -24^{*} \\ \mathrm{Kö} & 1 & 1 & 26^{* * *} & -14^{*} & 17 & 20 & -36^{* * *} \\ \mathrm{Ra} & 5 & 0 & 16^{* * *} & -10^{* *} & 7 & 13 & -18 \\ \mathrm{LL} & 9 & 0 & 2 & -5^{*} & 1 & -2 & -12\end{array}$

Subsoil samples

\begin{tabular}{lrlccrrr} 
Kö & 7 & 1 & $12^{* *}$ & $-24^{* * *}$ & 8 & -3 & -8 \\
Vi & 12 & 1 & $8^{*}$ & $-35^{* *}$ & 18 & -8 & 3 \\
\hline
\end{tabular}

Changes due to

$\begin{array}{crrr}\text { Inorganic } \mathrm{P} \text { extracted by } & \text { incubation } & \text { incubation with lime } & \text { liming } \\ \mathrm{NH}_{4} \mathrm{Cl} & 0 & 1 & 1 \\ \mathrm{NH}_{4} \mathrm{~F} & 7 & 19 & 12 \\ \mathrm{NaOH}^{\mathrm{H}_{2} \mathrm{SO}_{4}} & 11 & -8 & -19 \\ \text { Total } & -1 & 14 & 15 \\ \text { Organic P } & 17 & 26 & 9 \\ & -17 & -25 & -8\end{array}$

The observations made above agree with these average results.

The second incubation experiment was carried out with six very acid loam, clay loam, and silty clay samples, three of which, Vi 1 a, Vi 4 a, and Vi 6 a, were 
from the surface layer, and the samples $\mathrm{Vi} 1 \mathrm{c}$, Vi $4 \mathrm{c}$, and $\mathrm{Vi} 6 \mathrm{c}$ originated from the corresponding soils from the depth of about 40 to $60 \mathrm{~cm}$. In Table 4 are reported the increases or decreases in the various phosphorus fractions brought about by the incubation with different amounts of lime.

Table 4. Changes in fractions of soil $\mathrm{P}$ brought about by incubation at various lime status.

\begin{tabular}{|c|c|c|c|c|c|c|c|c|c|}
\hline & & \multirow{2}{*}{$\begin{array}{c}\mathrm{CaCo} \\
\mathrm{g} / \mathrm{kg}\end{array}$} & \multirow[b]{2}{*}{$\mathrm{pH}$} & \multicolumn{4}{|c|}{ Inorg. $\mathrm{P}$ ppm extracted by } & \multirow{2}{*}{$\begin{array}{c}\text { Total } \\
\text { inorg. P } \\
\text { extracted }\end{array}$} & \multirow{2}{*}{$\begin{array}{l}\text { Org. } \\
\text { P } \\
\text { ppm }\end{array}$} \\
\hline & & & & $\mathrm{NH}_{4} \mathrm{Cl}$ & $\mathrm{NH}_{4} \mathrm{~F}$ & $\mathrm{NaOH}$ & $\mathrm{H}_{2} \mathrm{SO}_{4}$ & & \\
\hline \multirow[t]{4}{*}{ Vi } & la & 0 & 3.5 & 0 & 1 & 13 & -2 & 12 & 8 \\
\hline & & 5 & 4.2 & 0 & $6^{*}$ & $18^{*}$ & -3 & 21 & 13 \\
\hline & & 10 & 5.1 & -1 & $8 * *$ & 2 & $7^{*}$ & 17 & -6 \\
\hline & & 20 & 6.5 & 1 & $24^{* * *}$ & $-42^{* * *}$ & $24 * * *$ & 7 & $-24^{*}$ \\
\hline \multirow[t]{4}{*}{ Vi } & $4 a$ & 0 & 4.2 & 0 & 4 & $19 * * *$ & 9 & $32^{* *}$ & -5 \\
\hline & & 5 & 5.4 & -1 & $17^{* * *}$ & $14^{* *}$ & 15 & $45^{* * *}$ & -17 \\
\hline & & 10 & 6.4 & 0 & $23^{* * *}$ & -6 & $21^{*}$ & $38^{* *}$ & $-40^{* * *}$ \\
\hline & & 20 & 6.8 & $2^{*}$ & $26^{* * *}$ & $-21^{* * *}$ & $37 * * *$ & $44^{* * *}$ & $-48 * * *$ \\
\hline \multirow[t]{4}{*}{ Vi } & $6 \mathrm{a}$ & 0 & 4.1 & 0 & 4 & $34^{*}$ & 0 & $38^{*}$ & 3 \\
\hline & & 5 & 5.5 & 0 & $16^{* *}$ & $54^{* * *}$ & 12 & $82^{* * *}$ & 18 \\
\hline & & 10 & 6.4 & 0 & $37 * * *$ & 14 & $23 * * *$ & $74^{* * *}$ & -12 \\
\hline & & 20 & 6.9 & $4^{* *}$ & $49^{* * *}$ & -15 & $50 * * *$ & $88^{* * *}$ & $-24^{*}$ \\
\hline \multirow[t]{4}{*}{ Vi } & 1c & 0 & 3.3 & 0 & - & -6 & -5 & -13 & - \\
\hline & & 5 & 3.9 & 0 & $5^{*}$ & -5 & -10 & $-20^{*}$ & 3 \\
\hline & & 10 & 4.8 & 0 & - & $-32^{* * *}$ & -4 & $-39^{* * *}$ & 1 \\
\hline & & 20 & 6.7 & 0 & $8 * * *$ & $-59^{* * *}$ & $24^{* * *}$ & $-27^{* *}$ & -6 \\
\hline \multirow[t]{4}{*}{ Vi } & $4 \mathrm{c}$ & 0 & 4.1 & 0 & - & $-22^{* * *}$ & -4 & $-27 * * *$ & - \\
\hline & & 5 & 6.3 & 0 & $3^{*}$ & $-42^{* * *}$ & -2 & $-40^{* * *}$ & -2 \\
\hline & & 10 & 6.9 & 0 & $6 * * *$ & $-48^{* * *}$ & 5 & $-36^{* * *}$ & -1 \\
\hline & & 20 & 7.0 & 1 & $6 * * *$ & $-66^{* * *}$ & -5 & $-64^{* * *}$ & -8 \\
\hline \multirow[t]{4}{*}{ Vi } & $6 \mathrm{c}$ & 0 & 4.1 & 0 & 2 & $-73^{* * *}$ & -8 & $-79 * * *$ & - \\
\hline & & 5 & 5.3 & 0 & 4 & $-72^{* * *}$ & 3 & $-65^{* * *}$ & 2 \\
\hline & & 10 & 6.0 & 0 & $7^{*}$ & $-78^{* * *}$ & $16^{* * *}$ & $-55^{* * *}$ & -19 \\
\hline & & 20 & 6.9 & 1 & $17^{* * *}$ & $-79^{* * *}$ & $36^{* * *}$ & -25 & -1 \\
\hline
\end{tabular}

There seems to be significant differences in the behaviour of the surface soils and the subsoils in the present experiment. The most striking feature in the latter samples is the marked decrease in the alkali-soluble fraction even in the distinctly acid samples incubated without lime. This decrease is not compensated by equal increases in the other fractions, and thus, there is considerable decline in the total amount of the extracted inorganic phosphorus. It is not likely in these cases that the results may be explained by the inaccuracy in the determinations. 
In the surface samples the effect of liming seems to be similar to that found in the first experiment; only these samples are so acid that first the highest application of lime has increased the $\mathrm{pH}$-values to the same level as one half of it did in most of the soils of the former experiment. The lowest application has not prevented an accumulation of alkali-soluble phosphorus, and it has caused a low increase in the $\mathrm{NH}_{4} \mathrm{~F}$-soluble fractions.

As could he expected, no mineralization of organic phosphorus did occur in the subsoil samples. Incubation of the surface samples without lime or with the lowest application of lime was also without effect in this respect, but the highest level of liming has caused a significant decrease in the organic phosphorus content; in the sample $\mathrm{Vi} 4 \mathrm{a}$, also the application of $10 \mathrm{~g} \mathrm{CaCO}_{3} / \mathrm{kg}$ has been effective. Particularly in the sample $\mathrm{Vi} 6$ a, the increases in the total inorganic phosphorus extracted are markedly higher than the corresponding decreases in the organic phosphorus content. Further studies are needed to show whether this disagreement is due to the fairly high contents of active iron and aluminium in the soil which may disturb the determination of the variously bound phosphorus, or whether changes in the solubility of the occluded forms are involved.

\section{Discussion}

In the first incubation experiment examined in this paper, the relatively heavy liming of the more or less acid samples, corresponding to at least $20000 \mathrm{~kg}$ $\mathrm{CaCO}_{3} / \mathrm{ha}$, tended to intensify the mineralization of organic phosphorus during the incubation, but only in a few cases this effect could be considered statistically significant. The influence of liming appeared to be most marked on the alkali-soluble inorganic fraction supposed to be phosphorus bound by iron and its compounds. The decrease in this fraction and the possible decrease in the organic phosphorus were usually compensated by corresponding increases in the acid-soluble and in the $\mathrm{NH}_{4} \mathrm{~F}$-soluble phosphorus. The former fraction is assumed to represent calciumbound phosphorus, mainly apatite like, and the latter one is taken to be phosphorus bound by aluminium and its oxides and hydroxides, although there is some evidence that in the procedure used dicalciumphosphate and perhaps also some other more easily soluble calcium phosphates than apatite may get into this fraction (17 etc.) In some samples liming caused increase in the easily soluble fraction, but also some contrary cases existed.

In the second experiment in which very acid samples known to be rich in active iron and aluminium were incubated, the conditions appeared to be more complicated and there is reason to suppose that the analytical procedures failed to some extent to indicate the real distribution of the phosphorus in these samples. Particularly, the behaviour of the subsoil samples needs further studies in this respect. In general, the increases in the acid-soluble and $\mathrm{NH}_{4} \mathrm{~F}$-soluble fractions, and, in the surface samples, the decreases in the alkali-soluble and organic forms tended to be the higher the heavier the application of lime had been.

Thus it seems - provided the analytical procedures were reliable enough that the effect of liming on the phosphorus conditions of acid soils in incubation 
experiments appears in the first place as a turning over of alkali-soluble inorganic phosphorus to acid-soluble or $\mathrm{NH}_{4} \mathrm{~F}$-soluble forms. The intensifying of the mineralization of organic phosphorus will usually be of minor importance.

The effect of liming on the mineralization of organic phosphorus would probably be more marked, if the incubation conditions were more favourable for the microorganisms. A higher incubation temperature, application of a certain amount of easily available energy-yielding material and nitrogen, and perhaps also inoculation with effective microbes could during a prolonged incubation make the influence of liming on the mobilization of organic phosphorus more distinct. However, the conditions would differ too much from those in the field.

Even the application of the present results to practice must be done with caution. It is likely that in the field liming tends to affect the soil phosphorus in a similar way as in these experiments, only to a lower degree. It is also likely that heavy applications of lime are needed to cause any distinct changes in the soil phosphorus conditions (cf. 22), and that the effect of 2000 to $5000 \mathrm{~kg} \mathrm{CaCO}_{3} / \mathrm{ha}$, usually recommended in Finland, will be relatively slight. An other thing is, that even the moderate liming may be favourable in preventing a rapid fixation of soluble fertilizer phosphorus in difficultly available forms.

\section{$S u m m$ ary}

The effect of liming on the soil phosphorus fractions was studied under the laboratory conditions. 28 samples of mineral soils ( $\mathrm{pH}$ in $0.01 \mathrm{M} \mathrm{CaCl}_{2}$ suspension 4.0 to 6.0 ) were incubated with 1 per cent $\mathrm{CaCO}_{3}$ or without lime for six months at about $18-20^{\circ} \mathrm{C}$. In an other experiment, six samples ( $\mathrm{pH}$ from 3.3 to 4.3 ) were incubated with $0,0.5,1$, or 2 per cent $\mathrm{CaCO}_{3}$ also for six months. At the end of the incubation period the soil $\mathrm{pH}$ in the limed samples of the first experiment ranged from $\mathrm{pH} 5.9$ to $\mathrm{pH} 7.5$, in the second experiment the highest application kept the soil $\mathrm{pH}$ at 6.5 to 7.0 .

In the air-dried samples the content of organic phosphorus and the fractions of inorganic phosphorus were determined, and the increases or decreases due to the incubation and liming were calculated.

Incubation without lime brought about decrease in the organic phosphorus content of several samples, and the presence of lime tended to intensify this effect, although only in a few cases the decrease due to liming was statistically significant. Liming also tended to increase the accumulation of $\mathrm{NH}_{4} \mathrm{~F}$-soluble inorganic phosphorus. The acid-soluble fraction was often increased in the limed samples but not in the unlimed ones. The alkali-soluble fraction was decreased in most soils in the limed samples, while it increased in some of the unlimed ones. In the second experiment the incubation caused marked decrease in the alkali-soluble phosphorus without a corresponding increase in the other phosphorus fractions determined in the subsoil samples.

It was concluded that in these experiments the relatively heavy liming in the first place affected the distribution of inorganic phosphorus increasing the $\mathrm{NH}_{4} \mathrm{~F}$ - 
soluble and acid-soluble forms at the expense of the alkali-soluble fraction. The effect on the mineralization of organic phosphorus seemed to be in most soils of minor importance.

\section{REFERENCES}

(1) Army, T. J. \& Miller, E. V. 1959. Effect of lime, soil type, and soil temperature on phosphorus nutrition of turnips grown on phosphorus-deficient soils. Agron. J. 51: $376-378$.

(2) BoHNe, H. 1949. Laboratoriumsversuche zur Frage der Mobilisierung der Bodenphosphorsäure durch Kalk auf sauren Böden. Zeitschr. Pflanzenern. Düng. Bodenk. 43: 37-55.

(3) - -1950 . Gefässversuche zur Frage des Einflusses einer Kalkung auf die Ernährung der Pflanzen mit Düngerphosphorsäure auf saurem Boden. Ibid. 48: 118-134.

(4) Chang, S. C. \& Jackson, M. L. 1957. Fractionation of soil phosphorus. Soil Sci. 84: $133-144$.

(5) $--\quad \&-,-1958$. Soil phosphorus fractions in some representative soils. J. Soil Sci. 9: 109119.

(6) Damsgand - Sorensen, P. 1946. Studier over Jordens Fosforsyreindhold. IV. Tidssk. f. Planteavl 50: $653-675$.

(7) Dorph-Petersen, K. 1953. Kalkningens virkning på sure jorders fosfattilstand. Ibid. 56: $177-221$.

(8) Foster, W. N. M. \& RUsSell, R. S. 1958. Factors affecting the ability of plants to absorb phosphate from soils III. J. Soil Sci. 9: $280-288$.

(9) Gericke, S. 1951. Beziehungen zwischen den Wachstumsfaktoren Kalk und Phosphorsäure. Zeitschr. Acker- u. Pflanzenbau 93: $141-168$.

(1C) Ghani, M. O. \& Aleem, S. A. 1942. Effect of liming on the transformation of phosphorus in acid soils. Indian J. Agric. Sci. 12: $873-882$.

(11) Halstead, R. L. \& Lapensee, J. M. \& Ivarson, K. C. 1963. Mineralization of soil organic phosphorus with particular reference to the effect of lime. Canad. J. Soil Sci. 43: 97 - 106.

(12) Heinemann, C-G. 1962. Der Einfluss von Düngung, pH-Wert und Wasserhaushalt auf die PVerteilung in Böden. Hannover. $90 \mathrm{~S}$.

(13) Hsu, P. H. \& JACKson, M. L. 1960. Inorganic phosphate transformations by chemical weathering in soils as influenced by $\mathrm{pH}$. Soil Sci. 90: $16-24$.

(14) KaILA, A. 1948. Viljelysmaan orgaanisesta fosforista. (Summary: On the organic phosphorus in cultivated soils.) Valt. Maat.koet. Julk. 129. Helsinki.

(15) - $\rightarrow-1961$. Effect of incubation and liming on the phosphorus fractions in soil. J. Sci. Soc, Agron. Finland 33: $185-193$.

(16) _- 1962. Determination of total organic phosphorus in samples of mineral soils. Ibid. 34: 187 196.

(17) -1963 . Fertilizer phosphorus in various fractions of soil phosphorus. Ibid. 35: 36-46.

(18) Parker, F. W. \& Tidmore, J. W. 1926. The influence of lime and phosphate fertilizers on the phosphorus content of the soil solution and soil extracts. Soil Sci. 21: 425-441.

(19) Russel, E. W. 1954. The availability of sorbed or fixed phosphates to plants. Trans. V Int. Cong. Soil Sci. II: $308-311$.

(20) SAlonen, M. 1946. Kalkituksen vaikutuksista maaperän orgaaniseen ja helppoliuokoiseen fosforiin. (Effect of liming on organic and easily soluble phosphorus of soil). J. Sci. Soc. Agron. Finland 18: 1 - 10 .

(21) SaUerlandt, W. 1936. Untersuchungen über die Salpeterbildung und die Umsetzungen der Phosphorsäure unter dem Einfluss von Kalkdüngung und dem Kalkgehalt der Böden. Zeitschr. Pflanzenern. Düng. Bodenk. 45; $129-153$.

(22) SAUnders, W. M. H. 1959. Effect of phosphate topdressing on a soil from andesitic volcanic ash. III New Zealand J. Agric. Res. 2: 659-665.

(23) Wrenshall, C. L. \& Dyer, W. J. \& Smith, G. R. 1940. Recent studies on the nature of soil organic phosphorus. Sci Agr. 20: $266-271$. 
(24) Aslander, A. 1954. An attempt to solve the phosphate problem in crop production so as to economize with the world supply of phosphates. Trans. Royal Inst. Techn. Stockholm, Sweden Nr 85.

\section{SELOSTUS.}

\section{KALKITUKSEN VAIKUTUKSESTA MAAN FOSFORIN MOBILISOITUMISEEN}

\section{Armi KaIla}

Tutkimuksessa yritetään selvittää muhituskokeiden perusteella kalkituksen vaikutusta maan fosforin fraktioihin. Todettiin, että verraten voimakas kalkitus ei yleensä näyttänyt parantavan merkitsevästi maan orgaanisen fosforin mineraloitumista. Sen sijaan kalkituksen vaikutus kohdistui maan epäorgaanisen fosforin fraktioihin siten, että se lisäsi ammoniumfluoridiin ja happoon liukenevaa fosforia emäkseen liukenevan fosforin kustannuksella. 